\title{
Costs of Taxation and the Benefits of Public Goods: The Role of Income Effects
}

Will Martin

World Bank
James E. Anderson

Boston College

\begin{abstract}
The fact that raising taxes can increase taxed labor supply through income effects is frequently used to justify very much lower measures of the marginal welfare cost of taxes and greater public good provision than indicated by traditional, compensated analyses. We confirm that this difference remains substantial with newer elasticity estimates, but show that either compensated or uncompensated measures of the marginal cost of funds can be used to evaluate the costs of taxation- and will provide the same result- as long as the income effects of both taxes and public good provision are incorporated in a consistent manner.
\end{abstract}

JEL Code: D61, F11, H21, H43.

Keywords: fiscal policy; second best; public goods; distortions; costs of taxation, marginal cost of funds; marginal excess burden, thought experiment.

Correspondence to: Will Martin, Development Research Group, World Bank, MSN3-303, 1818 H St NW, Washington DC 20433. Tel: 202473 3853; Fax 202522 1159; wmartin1@worldbank.org or Jim Anderson, Boston College, james.anderson.1@bc.edu. 


\section{Costs of Taxation and the Benefits of Public Goods: The Role of Income Effects}

Perhaps the central questions for government policy makers are what goods, in what quantities, they should provide, and what level and mix of taxes they should use to pay for them. Given the importance of these questions, one might expect reasonable agreement between economists on approaches to answering these questions. Currently, however, there are sharp differences in approaches to dealing with the income effects of taxation used to finance spending on public goods ${ }^{1}$, which lead to substantial differences in policy conclusions. The objective of this paper is to understand these differences, and to propose ways to reconcile them.

Stiglitz and Dasgupta (1971) and Atkinson and Stern (1974) identified an income effect ignored in previous work as a potentially important influence on the costs of taxes used to provide public goods. Triest (1990, p558), Ballard and Fullerton (1992) and Dahlby (1998) subsequently identified a consensus in the literature that estimates of the marginal cost of funds (MCF) raised for the provision of public goods should take these income effects into account. Mayshar (1990) suggested doing this by measuring compensated impacts on consumer welfare via an expenditure function, but using uncompensated government revenues by including the effects of tax-induced income changes on consumption of taxed goods.

Many studies have attributed important policy implications to this methodological change from traditional approaches to the marginal cost of funds (eg Browning 1976, 1987) that are based purely on compensated responses. Atkinson and Stern (1974, p127), Auerbach (1985, p112) and Ballard and Fullerton (1992, p122) suggest that the income effects associated with raising taxes may reduce the social costs of taxes on labor and hence

\footnotetext{
${ }^{1}$ We recognize that governments produce many goods that are not purely public goods. However, as noted by Devarajan, Squire and Suthiwart-Narueput (1997), governments, particularly in developing countries, are
} 
expand the range of public goods optimally provided by governments. Fullerton's (1991) analysis suggested that this effect could be large. On his calculations, the marginal efficiency cost of a dollar of US government revenue from taxes that bear on labor was only a quarter as large when these income effects were included ${ }^{2}$. Although Feldstein (1999) and Auten and Carroll (1999) found relatively smaller point estimates for the income effects of tax changes, the inclusion of these income effects still appears to reduce substantially the estimated marginal welfare costs of taxation.

As well as appearing to have major policy implications, including the income effects of taxation without those associated with public good provision has considerably complicated policy analysis. Ballard (1990), Mayshar (1990), Creedy (2000) and others have argued that the approach used to calculate the costs of providing government goods should differ from that used for evaluating balanced-budget changes in tax rates. Under this view, at least two MCF measures are seen to be needed, depending upon the type of "thought experiment" being conducted. One such measure, including the income effects of taxation, is to be used for balanced-budget experiments in which taxes are raised for use in "exhaustive" government spending; the other, with income effects excluded, for "differential-incidence" experiments such as changes in the taxes used to raise a particular amount of government revenue (Ballard 1990).

We think it potentially misleading to use different measures for the marginal cost of the same tax, identified with different fiscal "thought experiments" about the ultimate use of the funds raised. In contrast we show that either type of measure can be used to evaluate changes in public good provision, as long as the income effects of public good provision are treated symmetrically. ${ }^{3}$ It seems clear that the model used to make a full assessment of the

focussing their activities increasingly on providing public goods. A focus on pure public goods also helps clarify the key points we wish to make.

${ }^{2}$ For consistent and widely-adopted elasticity values, Fullerton (1991) estimated the Marginal Excess Burden (MEB) excluding these income effects-- which he defined as (MCF-1)-- of US labor taxes as 0.25 and the MEB including these income effects as 0.07 .

${ }^{3}$ As noted by Jones (2005), this does not mean that the income effects of public good provision should appear in the MCF, which we believe should focus on the costs of taxation. 
implications of tax and spending changes must represent the income effects of both tax measures and public good provision. A surprising feature of the way these income effects have been included in much of the literature is its partial nature. The tax revenue effects associated with real income changes due to provision of public goods have not been explicitly treated, except in a few studies such as Wildasin (1984), Slemrod and Yitzhaki (2001) and Jones (2005). We find that including income effects in a more comprehensive way substantially simplifies the analysis, allowing all income effects to be collected in a multiplier independent of the public goods being provided, along the lines of the Hatta (1977, p4) decomposition.

Some question whether measures of the marginal cost of funds are needed at all. Under this view, all that is needed is to specify a model, and to assess the welfare implications of funding the provision of particular public goods using particular combinations of taxes. This view rightly highlights the importance of specifying the model correctly, and raises the question of why previous models have resulted in such different answers.

Despite this view, we think that summary measures such as the marginal cost of funds are important for two reasons. One is that they allow policy analysis to be decentralized. Once a model has been developed which provides a relevant marginal cost of funds, those working on only part of the problem - such as those responsible for decisions on particular components of spending-can use this single parameter to adjust between benefits to the private sector and costs to the government in making their decisions about costs and benefits of public goods, without needing to have access to the complete model of the economy. A second reason is that measures of the marginal costs and marginal benefits of funds are useful in sensitivity analysis, which is important given the inevitable uncertainty about the true values of key parameters.

In section I, we provide a simple but general model, including all relevant income effects, that can be used to evaluate the benefits of public goods and the costs of taxation. 
Then, in Section II, we use it to estimate the implications of providing public goods and raising funds to pay for them. In Section III, we examine the implications of using compensated and uncompensated measures of the cost of taxation when evaluating provision of public goods. Then, Section IV examines the empirical effects of using different approaches in the much-studied case of the US income tax, both using traditional parameter values and those from more recent literature that takes into account more margins of adjustment than traditional labor supply elasticities. Section V concludes.

\section{The Model}

For our analysis, we need to represent government production; the behavior of consumers and producers, including the value to them of public goods; and the budget constraints of the government and the private sector. As well as allowing for conventional consumer demand and labor supply responses, the framework used must allow for the broader responses of taxable income to changes in taxes emphasized by authors such as Feldstein (1995, 1999) and Gruber and Saez (2002). Since governments must choose between investments in many different public goods, and many different possible taxes, a framework that allows for choices among these options is needed. To meet this need, we develop a model of a competitive single-household ${ }^{4}$ economy, incorporating a cost function to characterize government provision of public goods; an expenditure function to characterize behavior of the good-consuming and factor-supplying household; a profit function to represent production activities; and budget constraints for the private sector and government.

For simplicity and for consistency with most of the literature, we assume that market prices are fixed either because the production structure is linear or because of international

\footnotetext{
${ }^{4}$ Inclusion of multiple households would complicate the analysis without providing additional insights into the issues we consider. The valuation of the overall "household" for any public good includes, following Samuelson (1954), the sum of the marginal rates of substitution (MRS) of the individual people represented by this household, relative to a numeraire private good. In this analysis, we consider, in addition, the value of public goods in production.
} 
trade in a small economy ${ }^{5}$. Some private goods and services are not subject to taxes and their price is the numeraire. Market prices of private goods are shown by $\mathrm{p}^{*}$. The vector $\mathrm{p}$ refers to the prices of private goods and services faced by the household, and the vector of taxes is given by (p-p*). In this analysis, we consider only taxes on privately consumed or supplied goods, although generalizations to taxes on trade (Anderson and Martin 1996) or production are straightforward.

Costs of providing public goods are represented by a government cost function $\mathrm{c}\left(\mathrm{G}, \mathrm{p}^{*}, \tau\right)$ which shows the direct costs paid by the government for the inputs of private goods and services it uses to produce its exogenously-supplied vector of public goods, G. This cost is determined by market prices, $\mathrm{p}^{*}$, and a vector of efficiency parameters, $\tau$, as well as the government's supply of public goods, G. We assume that the government cost function is a well-behaved multi-input, multi-output cost function. This specification implies that governments seek to minimize the costs of producing their chosen vector of outputs. If costs are higher or input demands less price-responsive than they would be in a competitive market environment, this can be represented through the $\tau$ parameters, and/or lower price response parameters, $\mathrm{c}_{\mathrm{pp}}$. Standard minimum-value function properties imply that the first derivative of $\mathrm{c}$ with respect to $\mathrm{G}, \mathrm{c}_{\mathrm{G}}$, is a vector of the marginal direct costs of providing public goods. In Samuelson's (1954) terminology, $\mathrm{c}_{\mathrm{G}}$ corresponds to the marginal rate of transformation (MRT) between public goods and a private numeraire good.

Household behavior is represented by a function $e(p, G, u)$ which gives the minimum net expenditure on private goods necessary to maintain the utility level of a representative household given a vector of public goods, G. Goods and services supplied by households, such as labor, are represented by negative elements of $e_{p}$ and associated with negative elements of (p-p*). G appears in the expenditure function because public goods affect welfare directly through the cost-in terms of private goods-- of achieving a given

\footnotetext{
${ }^{5}$ Neary (1995) provides a framework for extending the analysis to the case where market prices change.
} 
level of utility. For example, government provision of police services may reduce the private expenditures on security needed to achieve the same level of utility.

Producer behavior must be included in the model because government activities are frequently designed to increase productivity in the production sector. It is represented by a constrained gross domestic product (GDP) function, $\mathrm{g}\left(\mathrm{p}^{*}, \mathrm{G}\right)$ which shows the net profits obtained from production activities after purchasing supplied factors and intermediate inputs at market prices, $p^{*}$. G appears in the GDP function because an increase in G may increase profits from production, as when government-provided roads lower the costs of transporting intermediate goods. The vector $\mathrm{p}$ does not appear because we focus on taxes levied on households.

Private sector behavior overall is represented by a net expenditure function, E, defined as the difference between the representative consumer's constrained expenditure ${ }^{6}$ function, $e(p, G, u)$, and the constrained gross domestic product function, $g\left(p^{*}, G\right)$.

Increases in elements of $\mathrm{G}$ which are valued by the household and/or producers will lower the private cost of achieving any given level of utility. These valuations are given by the vector $\mathrm{E}_{\mathrm{G}}$ which is negative for products valued by the private sector, and equal to minus the virtual price vector, $\pi$, or the marginal willingness to pay of the private sector for the goods ${ }^{7}$.

Budget constraints: The government budget constraint and the private-sector budget constraint are defined as:

$$
\begin{array}{lll}
\mathrm{c}\left(\mathrm{G}, \mathrm{p}^{*}, \tau\right)-\left[\mathrm{p}-\mathrm{p}^{*}\right]^{\prime} \mathrm{e}_{\mathrm{p}}(\mathrm{p}, \mathrm{G}, \mathrm{u}) & =\beta & \text { government budget constraint } \\
\mathrm{E}\left(\mathrm{p}, \mathrm{p}^{*}, \mathrm{G}, \mathrm{u}\right) & =\alpha \quad \text { private budget constraint } .
\end{array}
$$

The government budget constraint in (1) specifies that the government deficit, or spending on its input purchases less its revenue from taxes on consumption or factor

\footnotetext{
${ }^{6}$ The expenditure function may represent the supply of labor from the representative household using negative demands for supplied commodities.

${ }^{7}$ Note that $\pi$ incorporates Samuelson's sum of the valuations by individual consumers, and the valuation of the production sector, $\mathrm{g}_{\mathrm{G}}$.
} 
supply, is equal to an exogenous transfer from the rest of the world, $\beta$. The private-sector budget constraint, (2), sets net expenditure by the private sector equal to an exogenous transfer from the rest of the world, $\alpha$.

While we do not need these extensions, it is clear that the model could readily be generalized to include user charges on government-provided goods where these are feasible; lump-sum transfers from the government to the household; taxes on government agencies' purchases of inputs; and taxes on trade or on business inputs and outputs.

\section{Analyzing Provision of Public Goods}

We analyze a parametric change in $\mathrm{G}$, financed by an endogenous change in taxes, resulting in a change in the prices faced by households, dp. Totally differentiating (1) and (2) with respect to $G, p$ and $u$ we obtain:

$$
\begin{aligned}
& {\left[\mathrm{c}_{\mathrm{G}}{ }^{\prime}-\left(\mathrm{p}-\mathrm{p}^{*}\right)^{\prime} \mathrm{e}_{\mathrm{pG}}\right] \mathrm{dG}=\left[\mathrm{e}_{\mathrm{p}}{ }^{\prime}+\left(\mathrm{p}-\mathrm{p}^{*}\right)^{\prime} \mathrm{e}_{\mathrm{pp}}\right] \mathrm{dp}+\left(\mathrm{p}-\mathrm{p}^{*}\right)^{\prime} \mathrm{e}_{\mathrm{pu}} \mathrm{du}} \\
& \mathrm{E}_{\mathrm{G}}{ }^{\prime} \mathrm{dG}+\mathrm{e}_{\mathrm{p}}{ }^{\prime} \mathrm{dp}+\quad \mathrm{e}_{\mathrm{u}} \mathrm{du}=0 .
\end{aligned}
$$

The term pre-multiplying $\mathrm{dG}$ in (3) combines the direct cost of government outputs, $\mathrm{c}_{\mathrm{G}}$, with the impact of the change in $\mathrm{G}$ on government tax revenues through complementarity/substitutability relationships, $\left(\mathrm{p}-\mathrm{p}^{*}\right)^{\prime} \mathrm{e}_{\mathrm{pG}}$, originally identified by Diamond and Mirrlees (1971). This coefficient on dG is the full fiscal cost of the public output-the direct budget cost less the indirect, compensated implications of changes in $\mathrm{G}$ for tax revenues.

To maintain fiscal balance when $\mathrm{G}$ increases, taxes must be raised through a change in $\mathrm{p}$, dp, sufficient to pay the full fiscal cost, taking into account the change in the level of the taxed activity resulting from the substitution effects of tax rate changes and public good

supply, and the income effects of all of the changes involved. The term in square brackets on the right-hand side of (3) decomposes the equilibrating tax revenue change into two key components. The $\mathrm{e}_{\mathrm{p}} \mathrm{dp}$ term is the direct impact of the tax changes on tax revenues. The (p$\left.\mathrm{p}^{*}\right)^{\prime} \mathrm{e}_{\mathrm{pp}}$ term is the tax revenue loss and the marginal dead weight loss resulting from the 
household's compensated responses to changes in prices brought about by changes in taxes.

In maintaining fiscal balance, governments typically have a number of different taxes available to them, and the cost of raising funds depends on which taxes are changed, and by how much. An intuitively-appealing tax package is one which expresses changes in tax rates relative to market prices, $\mathrm{p}^{*}$, of taxable goods-- if units are chosen such that the market prices of these goods are initially one hundred, then the resulting changes in the prices paid by households can be interpreted as percentage point changes in tax rates. Alternatively, a tax package might be defined in terms of changes in the household prices of taxable goods, $\mathrm{p},-$ a potentially attractive approach if the initial tax mix is close to optimal. A tax package might also be defined in terms of its impact on initially-applied tax rates, as in Feldstein (1999, p678).

When seeking fiscal balance, governments frequently raise tax rates on different goods by different amounts, and may even lower some tax rates. Such tax packages can be represented by a diagonal matrix, $\mathrm{W}$, of weights on different price variables - where a unitary weight means full inclusion of a good in the tax reform package, and zero implies its exclusion ${ }^{8}$. Given a W matrix and a chosen price base, a vector of price changes may be defined as $d p=\_. d \phi$ where $\_$is the product of $\mathrm{W}$ and the chosen base price vector, and $\mathrm{d} \phi$ is a scalar used to find the overall size of the change in tax rates needed to achieve fiscal balance. For a tax change specified relative to market prices, ${ }_{-}=\mathrm{W} . \mathrm{p}^{*}$. As noted by Sandmo (1998, p378), whenever taxes are non-optimal, the choice of prices to be adjusted, and the relative magnitudes of the price changes to be imposed, may have important impacts - for example, some tax reforms, such as those involving reductions in high tax rates and increases in low tax rates, may yield a compensated MCF less than unity ${ }^{9}$

\footnotetext{
${ }^{8}$ Packages involving weights above, or below, unity might also be used to increase or decrease the importance of particular taxes relative to others in the initial tax mix.

${ }^{9}$ As is emphasized by Drèze and Stern (1985, p919), there is an element of arbitrariness in specifying how revenue impacts will be dealt with, and the combination of a bad project and a good tax reform could result
} 
For any specified tax package, we can solve equation (3) for the scalar $\mathrm{d} \phi$ needed to maintain fiscal balance:

$$
\mathrm{d} \phi=1 /\left[\mathrm{e}_{\mathrm{p}}{ }^{\prime}-+\left(\mathrm{p}-\mathrm{p}^{*}\right)^{\prime} \mathrm{e}_{\mathrm{pp}-}\right] \cdot\left[\left\{\mathrm{c}_{\mathrm{G}}{ }^{\prime}-\left(\mathrm{p}-\mathrm{p}^{*}\right)^{\prime} \mathrm{e}_{\mathrm{pG}}\right\} \mathrm{dG}-\left(\mathrm{p}-\mathrm{p}^{*}\right)^{\prime} \mathrm{e}_{\mathrm{pu}} \mathrm{du}\right]
$$

The term dp in (4) may be replaced by _.d_ with $d_{-}$obtained using (5). Then, using $\pi$ for the virtual price of public goods, we obtain:

$$
\left(1-\operatorname{MCF}\left(p-p^{*}\right)_{-1}^{\prime}\right) \cdot e_{u} d u=\left[\pi^{\prime}-\operatorname{MCF}\left\{c_{G}{ }^{\prime}-\left(p-p^{*}\right)^{\prime} e_{p G}\right\}\right] d G
$$

or

$$
\mathrm{e}_{\mathrm{u}} \mathrm{du}=\operatorname{FXM} \cdot\left[\pi^{\prime}-\operatorname{MCF}\left\{\mathrm{c}_{\mathrm{G}}{ }^{\prime}-\left(\mathrm{p}-\mathrm{p}^{*}\right)^{\prime} \mathrm{e}_{\mathrm{pG}}\right\}\right] \mathrm{dG}
$$

where the FXM term $\left(=1 /\left(1-\mathrm{MCF}\left(\mathrm{p}-\mathrm{p}^{*}\right)_{-1}^{\prime}\right)\right)$, to be explained below, is the welfare effect of a transfer from the rest of the world to the private sector; MCF is the compensated Marginal Cost of Funds, also explained below; and $\chi_{I}$ is a vector of income effects, $e_{p u} / e_{u}$. The expression in curly brackets is the direct cost of the good to the government adjusted by the impact of its provision on tax revenues - the fiscal cost of the good identified above. The term in square brackets on the right hand side of (6) and (7) is a net impact of the change in $\mathrm{G}$ - the difference between its virtual price, $\pi$, and the product of the MCF and the fiscal cost of the public good.

The FXM term in equation (7), frequently termed the foreign exchange multiplier (see Anderson and Neary 1992, p62, for a discussion of the concept), measures the impact of a change in the transfer from the rest of the world to the private sector, $d_{-}$, on a moneymetric measure of household welfare, as shown in the Appendix. Note that the FXM term

in acceptance of a project that has lower returns than one evaluated against a higher MCF. A pragmatic solution, consistent with the widespread practice of calculating generalized MCFs for each economy (see Devarajan, Squire and Suthiwart-Narueput 1997), might be to estimate a feasible marginal tax mix for revenue expansion (or reduction), and to use this same MCF in the evaluation of all spending alternatives. 
depends upon all of the cases where income effects operate on goods that are subject to initial taxes, and hence affect the value of the inner product $\left(\mathrm{p}-\mathrm{p}^{*}\right)_{-_{I}}^{\prime}$.

The FXM coefficient is not generally unity in distorted economies because a transfer of $\$ 1$ to the private sector sets off spending effects that affect tax revenues whenever any tax is levied on an income-responsive good. If the additional income in the hands of the private sector is spent on normal goods subject to positive taxes, there will be a second-round benefit from reductions in distorting taxes and FXM will be greater than one. If, by contrast, the additional income increases consumption of untaxed goods, such as leisure, and hence reduces the supply of taxed goods such as labor, FXM may be less than one. If these negative income effects were sufficiently strong, FXM could conceivably be negative in sign. This seems a curiosum, since it implies a situation where the welfare of the private sector is reduced by receiving unrequited, unrestricted transfers from abroad ${ }^{10}$. The conditions that define a positive FXM must be met even if $\mathrm{e}_{\mathrm{u}} \mathrm{du}$ is used as the criterion. If FXM is negative, then the uncompensated money-metric measure of welfare change, $e_{u} d u$ in equation (7), will also respond in the "wrong" way to tax changes.

As long as the FXM term is assuredly positive, policy choices can be based solely on the term in square brackets in equation (6), which weighs the benefits of the project to the household against the fiscal costs multiplied by the MCF. Our MCF term is defined as

$$
\mathrm{MCF}=\mathrm{e}_{\mathrm{p}}{ }^{\prime}-\left[\mathrm{e}_{\mathrm{p}}{ }^{\prime}-+\left(\mathrm{p}-\mathrm{p}^{*}\right)^{\prime} \mathrm{e}_{\mathrm{pp}-}\right]
$$

As is shown in the Appendix, this MCF is the compensation to the private sector needed to maintain the initial utility level when the government reduces its transfer from the rest of the world by $\mathrm{d} \beta$ and meets its budget constraint by raising taxes. Thus, the MCF maps income in the hands of government (the social income of Little and Mirrlees (1974)) into income in the hands of the private sector ${ }^{11}$.

\footnotetext{
${ }^{10}$ Hatta (1977) and Anderson and Neary (1992) discuss more formal conditions.

${ }^{11}$ In the cost-benefit literature (see, for example, Squire 1989, p1104), government outputs are typically sold to the private sector at their marginal value, allowing costs and benefits to be presented either in terms of income in the hands of government or the hands of the private sector. In our application, the costs are
} 
This MCF term is a compensated version of the marginal efficiency cost of funds (MECF) defined by Slemrod and Yitzhaki (2001, p192). For a single-tax economy, it corresponds to the familiar compensated MCF of Mayshar (1991, p1329). Its numerator is the cost to taxpayers from a marginal change in the uniform tax surcharge, $\phi$. Its denominator is the increase in revenue achieved with the (compensated) household and government agencies free to respond to the incentives created by the tax changes. Because the numerator of the MCF will generally be larger than the denominator, the MCF will normally be greater than one. Note that the columns of $e_{p p}$ relevant to the value of the MCF are only those that correspond to a non-zero element in the vector _. This contrasts with FXM, which necessarily involves all initial taxes on products with non-zero income effects.

Intuitively, the MCF measures the inefficiency of tax policy, as it generally costs more than a dollar of private income to raise fiscal revenues by one dollar. An important special case is the MCF of a tax on goods supplied or demanded by the household with zero compensated price effects relative to any price. In this case, the MCF is unity since, by symmetry, the relevant columns of $e_{p p}$ contain only zero elements. This intuitive property is not necessarily shared by uncompensated measures, where income effects from changes in lump-sum taxes will influence excess demands for taxed private goods whenever there are initially-taxed goods with non-zero income effects.

Like Schöb (1994), Slemrod and Yitzhaki (2001) and Jones (2005), but in contrast with Ballard and Fullerton (1992, p115) and Snow and Warren (1996), we exclude the effects of public good provision on taxed private goods from the MCF and the related marginal welfare cost of taxation, which is MCF-1 using our compensated welfare measure. The compensated welfare effects resulting from changes in public-good provision, ( $\mathrm{p}$ $\left.\mathrm{p}^{*}\right)^{\prime} \mathrm{e}_{\mathrm{pG}} \cdot \mathrm{dG}$, can usefully be thought of as part of the fiscal cost of providing particular public goods (as in equations (6) and (7)), and dealt with separately from the costs of

borne by government and the marginal benefits, $\pi$, accrue to the private sector, making conversion necessary. 
raising revenues. This allows the MCF to be estimated independently from decisions about the type of public goods to be supplied, and avoids the stumbling block to progress in obtaining improved estimates of the marginal welfare cost of taxation identified by Snow and Warren (1996, p303) - the perceived need to include estimates of the impact of government spending on taxed activities in the MCF.

Equation (6) has an extremely simple, powerful interpretation. Whether a change in government outputs is welfare-improving depends on whether the direct valuation of the change by agents, $\pi^{\prime} \mathrm{dG}$ (or_MRS.dG in the notation of Ballard and Fullerton (1992, p118), plus $\mathrm{g}_{\mathrm{G}}$ ) exceeds the compensated MCF times the fiscal costs (direct plus indirect, or the MRT plus induced tax revenue effects) of the good. This is a key result, and provides a very simple guide to fiscal policy decisions for pure public goods. It is, in effect, a reaffirmation of the Pigou (1947, p34) doctrine, which has been interpreted (see Atkinson

and Stern 1974; Auerbach 1985) as basing the marginal cost of funds on compensated demand responses. As we will see, this result arises because we have gathered all of the income effects on the left hand side of equation (6), rather than treating the income effects due to tax changes separately from those due to provision of public goods.

Equation (6) also reveals the fundamental problem with the widely-cited (see $\mathrm{Ng}$ 2000) conclusion of Kaplow $(1996,2004)$ that the MCF of funds used for public good provision should be unity. While Kaplow correctly includes both the spending effects arising from both provision of public goods and those resulting from raising taxes to pay for them, he ignores the substitution effects inherent in the MCF when concluding that the supply of labor is unaffected (p514) when taxes are raised by exactly enough to eliminate the welfare benefits arising from provision of the good. While such a compensating change in taxes can exactly offset the income effects of public-good provision, it cannot be expected to offset the substitution effects of the tax change as well.

\section{Compensated vs. Uncompensated Evaluation Methods}


An uncompensated measure of the marginal cost of funds can also be obtained from equations (3) and (4). Substituting for $e_{u} d u$ from equation (4) into equation (3) yields an expression:

$$
\left[\mathrm{c}_{\mathrm{G}}{ }^{\prime}-\left(\mathrm{p}-\mathrm{p}^{*}\right)^{\prime}\left\{\mathrm{e}_{\mathrm{pG}}+{ }_{-} \tau^{\prime}\right\}\right] \mathrm{dG}=\left[\mathrm{e}_{\mathrm{p}}{ }^{\prime}+\left(\mathrm{p}-\mathrm{p}^{*}\right)^{\prime}\left\{\mathrm{e}_{\mathrm{pp}}{ }_{-{ }_{\mathrm{I}}} \mathrm{e}_{\mathrm{p}}{ }^{\prime}\right\}\right] \mathrm{dp}
$$

As in the previous case, we define a policy reform such that $\mathrm{dp}={ }_{-} . \mathrm{d}_{-}$and use the government budget constraint to solve for the change in tax rates needed to maintain government budget balance. This yields:

$$
\mathrm{d}_{-}=1 /\left[\mathrm{e}_{\mathrm{p}}{ }^{\prime}++\left(\mathrm{p}-\mathrm{p}^{*}\right)^{\prime}\left(\mathrm{e}_{\mathrm{pp}}{ }_{--_{\mathrm{I}}} \mathrm{e}_{\mathrm{p}}\right)_{-}\right] \cdot\left[\mathrm{c}_{\mathrm{G}}{ }^{\prime}-\left(\mathrm{p}-\mathrm{p}^{*}\right)^{\prime}\left(\mathrm{e}_{\mathrm{pG}}+{ }_{-\mathrm{I}} \pi^{\prime}\right)\right] \mathrm{dG}
$$

Substituting (10) into (4) yields a money-metric expression paralleling (7) for the welfare impact of $\mathrm{dG}$ :

$$
\mathrm{e}_{\mathrm{u}} \mathrm{du}=\left[\pi^{\prime}-\mathrm{MMCF} \cdot\left\{\mathrm{c}_{\mathrm{G}}{ }^{\prime}-\left(\mathrm{p}-\mathrm{p}^{*}\right)^{\prime}\left(\mathrm{e}_{\mathrm{pG}}{ }^{+}-\pi^{\prime}\right)\right\}\right] \mathrm{dG}
$$

where $\mathrm{MMCF}=\mathrm{e}_{\mathrm{p}}{ }^{\prime}-\left[\mathrm{e}_{\mathrm{p}}{ }^{\prime}-+\left(\mathrm{p}-\mathrm{p}^{*}\right)^{\prime}\left(\mathrm{e}_{\mathrm{pp}}{ }^{-}{ }_{\mathrm{I}} \mathrm{e}_{\mathrm{p}}{ }^{\prime}\right)_{-}\right]$is an uncompensated measure of the marginal cost of funds. For a single tax on labor, this is exactly the uncompensated MCF of Mayshar (1991, p1329).

Note that the response of taxed private good demand/supply to the provision of public goods in equation (11) is also an uncompensated impact, $\left(\mathrm{e}_{\mathrm{pG}}+-\pi \tau^{\prime}\right)$. If the uncompensated MMCF measure is to be used, uncompensated measures must be used throughout the model. If the inclusion of income effects on taxed goods in the denominator of the MMCF, through the term ${ }_{-1} \mathrm{e}_{\mathrm{p}}{ }^{\prime}$, reduces the measured cost of taxation, this benefit is offset by the addition of the term $\operatorname{MMCF}\left(\mathrm{p}_{-} \mathrm{p}^{*}\right)_{-} \pi^{\prime} \mathrm{dG}$, which takes into account the income effects of providing public goods.

Since the overall income effect of raising taxes and using them to pay for a marginal unit of public goods is zero at the optimum, these two spending effects must exactly counterbalance each other at the optimum - as is evident from the right hand side of equation (6). This is why the use of the uncompensated measures has no policy significance. Despite what is frequently suggested (see Ballard and Fullerton 1992, p119), 
this lack of policy significance applies whether or not the public good is a perfect or an imperfect substitute for cash. All that is required is that the public good affects welfare. Unfortunately, many studies advocating the use of the MMCF approach have not noted the consequent need to adjust the measured benefits of public goods for the income effects of public good provision on tax revenues - creating an impression of policy significance.

Our preference is for the use of the compensated MCF measure where possible. A key advantage of a compensated measure is the ability to make comparisons across countries. The compensated measure is a measure of the actual transfer from outside the system to the private sector that would have the same effect on welfare as provision of the public good. If a money metric measure is used, it is not possible to make comparisons across countries without dividing each country's measured benefit by its own FXM. When evaluating, for example, the benefits of a trade agreement or an internationally co-ordinated tax reform, use of the compensated approach allows comparison and addition of the benefits accruing to all countries and calculation of any compensation - or side-payments- that might be needed to maintain utility levels.

The MMCF approach also has a number of practical disadvantages. One arises from the absence of the intuitive feature of the MCF that the welfare costs of raising funds through lump sum taxes are necessarily unity. Even if the specific tax package being used to finance a marginal expansion of public-good provision falls only on goods that are completely inelastic in demand/supply, the MMCF need not be unity if there are some taxed private goods with non-zero income effects in the initial tax base. When the uncompensated approach is used, the Marginal Excess Burden (MEB) of the tax must be calculated by subtracting the foreign exchange multiplier, rather than unity, from the MCF. The need to make this adjustment has led to errors and confusion in some subsequent papers, even though the need to make some adjustment of this type was pointed out by Triest (1990).

As we have shown, only one type of measure is needed for analysis of public good provision, and standardizing on the compensated measure would reduce the counter- 
productive proliferation of alternative welfare measures that has been the source of much confusion. If, however, only an uncompensated measure is available, then equation (11) makes clear that it can be used to evaluate provision of public goods as long as the income effects resulting from the provision of public goods are taken into account in assessing the fiscal price of the good.

The one case in which the MMCF provides a sufficient adjustment for comparing the benefits of public goods and their cost is the situation considered by Ballard and Fullerton (1992, p124), where public goods and taxed private goods are "ordinary independents". In this case, substitution effects on tax revenues exactly offset the income effects from provision of the public goods for all taxed goods, so that $\left(\mathrm{e}_{\mathrm{pG}}+{ }_{-} \tau^{\prime}\right) \mathrm{dG}=0^{12}$ and a special case of equation (11) applies:

$$
\mathrm{e}_{\mathrm{u}} \mathrm{du}=\left[\pi^{\prime}-\mathrm{MMCF} \cdot \mathrm{c}_{\mathrm{G}}{ }^{\prime}\right] \mathrm{dG}
$$

However, this situation relies, at best, on pure coincidence. Further, it is infeasible in cases where income and substitution effects operate in the same direction, such as when an increase in public good provision reduces the volume of taxed goods through substitution effects (as when public goods are complements to leisure, like roads to the beach) and the real income gains due to public good provision also reduce the volume of taxed goods (as with a tax on labor supply).

Many studies assume away substitution and income effects of public good provision by invoking separability between the public good and taxed private goods. However, a situation where the public good has no impact on consumption of taxed private goods cannot be obtained (as in Ballard and Fullerton 1992, p126 and many other studies) simply by invoking separability. While separability places restrictions on compensated substitution effects, it need not eliminate them (Deaton and Muellbauer, 1980, p128). Even

\footnotetext{
${ }^{12}$ This condition for taxed goods is sufficient, rather than necessary. A weaker condition, that (p $\left.\mathrm{p}^{*}\right)^{\prime}\left(\mathrm{e}_{\mathrm{pG}}+{ }_{-\mathrm{I}} \pi^{\prime}\right)=0$, would allow use of $\mathrm{MMCF}$ without requiring that there be zero impacts on consumption of individual taxed goods.
} 
if it did, ordinary independence need not apply-- the income effects of public good provision would need to be taken into account.

Examination of equations (6), (7) and (11) also raises questions about the widelyaccepted assignment (see Ballard 1990) of compensated measures of the marginal cost of funds to the case of differential tax changes with constant revenue, and uncompensated measures to the cost of public funds raised for the provision of public goods. Equations (6) and (11) show clearly that either the compensated or the uncompensated MCF can be used to measure the cost of raising public funds for the provision of public goods.

The comparison of (6) with (7) and (11) makes clear that the real distinction between measures for the impact of public good provision on welfare is the choice of numeraire rather than of "thought experiment". Equation (6) measures the welfare impact of public good provision in terms of the compensation to the private sector from outside the economy needed to leave the private sector indifferent to a marginal change in provision of public goods. Equations (7) and (11) measure the impact in terms of the domestic private sector's money-metric valuation of the change. Alternative measures, more in the spirit of Little and Mirrlees (1974), that use income in the hands of government as the numeraire, could be obtained by dividing (7), (11) or equation (14) in the Appendix throughout by FXM.MCF, as in Jones (2005). As might be expected, the choice of numeraire is irrelevant to the policy conclusion.

\section{Does It Still Matter?}

Much of the literature on the costs of raising funds for public good provision in the early 1990s focused on the difference between the compensated and uncompensated measures, and its apparent policy implications when labor supply responds to tax changes. Ballard and Fullerton (1992) provide the clearest example of this approach. More recent

papers, such as Feldstein $(1995,1999)$ and Gruber and Saez (2002), have tended to focus on the breadth of substitution possibilities in response to tax changes, and to place less 
emphasis on income effects in measuring the costs of raising taxes. An important question is whether the distinction between the compensated and uncompensated measures matters when these broader measures of response are considered.

To examine this question, we focus on the case of US income taxes, for which numerous MCF estimates of different types are available ${ }^{13}$, and for which Snow and Warren (1996) have provided comparable measures for a number of earlier studies. These earlier studies focused on the response of labor supply alone to the income tax and frequently found the difference between compensated and uncompensated measures to be enormous in proportional terms. We update Snow and Warren's comparison by adding estimates based on studies using the broader definition of factor-supply responses to tax incentives that has characterized the literature on the marginal cost of funds since Feldstein's influential (1995) paper.

Following Snow and Warren (1996, p294), we designate the Marginal Welfare Cost of taxation as the Marginal Cost of Funds minus unity in both compensated $\left(\mathrm{MWC}^{\mathrm{C}}\right)$ and uncompensated $\left(\mathrm{MWC}^{\mathrm{U}}\right)$ cases. $\mathrm{MWC}^{\mathrm{U}}$ need not be a measure of the marginal welfare cost of a distorting tax relative to a lump-sum tax, since the uncompensated MCF of a lump-sum tax may be less than unity if the negative income effects associated with a tax increase raise the volume of taxed goods consumed or supplied (see Triest 1990). However, comparison of $\mathrm{MWC}^{\mathrm{C}}$ and $\mathrm{MWC}^{\mathrm{U}}$ does indicate the reduction in the marginal welfare cost of taxation implied when an MMCF estimate is used in place of MCF in equation (6).

Table 1. Estimates of the Marginal Welfare Cost of US Income/Labor taxes.

\begin{tabular}{|l|c|c|c|}
\hline \multicolumn{1}{|c|}{ Author/Year } & MWC $^{\mathrm{C}}$ & MWC $^{\mathrm{U}}$ & \% Reduction using MWC $^{\mathrm{U}}$ \\
\hline Stuart (1984) & 0.212 & 0.076 & 64 \\
\hline Ballard (1990) & $0.197^{\mathrm{a}}$ & 0.030 & 85 \\
\hline Fullerton (1991) & 0.25 & 0.07 & 72 \\
\hline
\end{tabular}

${ }^{13}$ As noted by Jones (2005, Table 7.2), only compensated measures are available for many other countries. 


\begin{tabular}{|c|c|c|c|}
\hline Feldstein (1999) & $0.57^{\mathrm{b}}$ & 0.27 & 53 \\
\hline \multicolumn{4}{|c|}{ 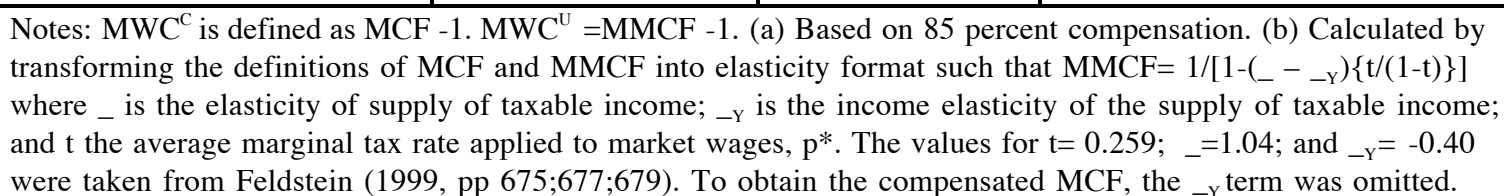 } \\
\hline
\end{tabular}

In Table 1, the estimates based on Stuart (1984) and Ballard (1990) are those recalculated for consistency by Snow and Warren (1996, p301). The estimates attributed to Fullerton (1991, p303) are from his Table 1. All of these estimates are based on traditional values of response parameters, such as the compensated labor supply elasticity of 0.2 and the uncompensated labor supply elasticity of zero used in Fullerton (1991, p306).

The estimates in the final row of Table 1 were derived for a small across-the-board increase in the income tax rate on income in all tax brackets (including the currently taxexempt low income bracket) using the average marginal tax rate (0.259) and the estimates of substitution (1.04) and income (-0.40) elasticities relative to the after-tax share proposed by Feldstein (1999). Our estimate of the compensated marginal welfare cost per dollar of taxation is based on Feldstein's average marginal tax rate and would be expected to be lower than Feldstein's (1999, p678) estimate of $\$ 0.78$ per dollar of revenue because Feldstein's estimate is based on proportional increases in existing tax rates, and therefore does not raise taxes in the zero-bracket group, where the MWC is zero ${ }^{14}$, while we must raise taxes in all income groups since we use information on the average marginal tax rate, rather than information on individual taxpayers.

The point estimates of 0.43 and -0.135 for substitution and income elasticities of taxable income estimated by Gruber and Saez (2002, p19), while lower than Feldstein's, point to a broadly similar relativity between the substitution and income elasticities. Gruber and Saez were unable to obtain statistically significant estimates of the income effect, although theory and other empirical evidence point strongly to the existence of a nonzero

\footnotetext{
${ }^{14}$ Parry (2002) makes this point, that tax deductions and exclusions can affect the marginal welfare cost of taxation.
} 
income effect on the aggregate supply of income-earning factors. With Auten and Carroll's (1999, p693) statistically significant estimates of 0.55 and -0.166 for substitution and income effects, and the average marginal rate provided by Feldstein, the $\mathrm{MWC}^{\mathrm{C}}$ is 0.24 , the $\mathrm{MWC}^{\mathrm{U}}$ is 0.15 , and the reduction in the MWC implied by using $\mathrm{MWC}^{\mathrm{U}}$ is 9 cents in the dollar, or 38 percent of its original value. While the reduction in the MWC is smaller than with Feldstein's elasticities, it would still be large enough to have major implications for real-world decisions.

The key feature of Table 1 for our purposes is the continuing importance of income effects. For traditional values of the behavioral parameters, such as those used in the first three rows of the table, the uncompensated approach yields much smaller estimates of the marginal welfare cost of taxation, with the estimated marginal welfare cost of taxation falling close to zero. While the recent literature, including Feldstein $(1995,1999)$ and Gruber and Saez (2002), has tended to focus on substitution rather than income effects, our experiment with an increase in tax rates on all income shows that income effects remain very important even given the parameters chosen by Feldstein. With Feldstein's parameters, moving from an uncompensated marginal welfare cost to a compensated measure more than doubles the cost, raising it by over 30 cents in the dollar. This does not mean that income effects will always be important-in the case of an increase in progressivity considered by Feldstein (1999, p679, Section C), the income effects were dominated by substitution effects. However, they were considerably more important in reducing the measured cost of an increase in all tax rates (other than the zero rate) in Feldstein (1997, p203).

\section{Conclusions}

In this paper, we provide a general framework to guide decisions on the benefits of government provision of goods and services. The model we provide is simple but general, incorporating the benefits of public goods to households and producers; including a very 
general multiple-output, multiple-input characterization of public good provision; and taking full account of the government's financing options through packages of tax changes.

Our analysis enables us to provide a simple rule for evaluating government provision of public goods which reinstates Pigou's (1947) conclusion that the costs of providing public goods must take into account the marginal costs of raising government revenues. Further, the adjustment for the marginal cost of government funds (MCF) should be a compensated measure, unless one is willing to adjust the measured benefits of public spending for the income-effect-determined changes in tax revenues resulting from provision of public goods.

If the income effects associated with tax-induced changes in prices and the income effects associated with provision of public goods are taken into account, considerable simplification is possible, with the tax-revenue effects associated with both sets of income changes being collected together in a multiplier term. Another important simplification arises from reorganizing the impacts of government provision into a fiscal cost that may be project-specific - this allows us to cut Snow and Warren's (1996) Gordian Knot requiring estimation of the impacts of government spending on private sector behavior before progress can be made on measuring MCFs.

We show that either the compensated or the uncompensated measures can be used for policy guidance, as long as the approach is followed consistently, and all relevant income terms are included. We prefer the compensated measures on the grounds that they provide measures of potential compensating - or inducing-international transfers, and that they embody the useful benchmark of an MCF of unity for a lump-sum tax, even when there are other income-responsive taxes in the initial tax base. However, the fact that one can use either measure means that only one measure of the $\mathrm{MCF}$ - whether compensated or uncompensated-is needed for public good provision based on a specified package of marginal tax adjustments. Since there is a clear consensus (see Ballard 1990) that the compensated measure can be used for differential-incidence problems in which taxes are 
changed while holding government revenues constant, the same compensated MCF can be used for both differential-incidence and balanced-budget analysis.

Once the income effects associated with the provision of public goods are taken into account, the use of the uncompensated marginal cost of funds has none of the profound policy implications attributed to it by Ballard and Fullerton (1992, p122) and many other authors. At least in the well-researched case of US income taxes, this implies a considerable increase in the measured cost of raising government revenues to fund provision of public goods relative to estimates based on the current consensus (see, for example, Dahlby 1998) that the marginal cost of funds for public goods should be based on uncompensated elasticities. While recent, and more complete, representation of the substitution effects of taxation on income generation has tended to reduce the importance of spending effects, the difference between the compensated and uncompensated measures remains very important-moving to compensated measures roughly doubles the estimated marginal welfare cost of US income taxation when Feldstein's (1999) parameter estimates are used. 


\section{Appendix: Interpreting the FXM and the MCF}

To interpret the FXM and the MCF, we begin by differentiating the government and private sector budget constraints with respect to $\alpha, \beta, \mathrm{p}$ and $\mathrm{u}$, with $\mathrm{G}$ held constant. In this situation, the counterparts of equations (3) and (4) are:

$$
\begin{aligned}
& e_{p}^{\prime} d p-\left(p-p^{*}\right)^{\prime} e_{p p} d p-\left(p-p^{*}\right) e_{p u} d u=d \beta \\
& e_{p}{ }_{p} d p+e_{u} d u=d \alpha
\end{aligned}
$$

To interpret the FXM, we consider the case of an exogenous d $\alpha$ where dp and du are endogenously determined, and $\mathrm{d} \beta=0$. As in Section II, we let $\mathrm{d} p=\_\mathrm{d} \varphi$ and solve $\left(3^{\prime}\right)$ for the scalar $\mathrm{d} \varphi$ yielding:

$$
\mathrm{d} \varphi=-1 /\left[\mathrm{e}_{\mathrm{p}}{ }^{\prime}-+\left(\mathrm{p}-\mathrm{p}^{*}\right)^{\prime} \mathrm{e}_{\mathrm{p} p-}\right] \cdot\left(\mathrm{p}-\mathrm{p}^{*}\right) \mathrm{e}_{\mathrm{pu}} \mathrm{du}
$$

Substituting the resulting expression for dp into (4') and rearranging yields:

$$
\begin{aligned}
& -e_{p-} /\left[e_{p}{ }^{\prime}++\left(p-p^{*}\right)^{\prime} e_{p p-}\right] \cdot\left(p-p^{*}\right)\left(e_{p u} / e_{u}\right) e_{u} d u+e_{u} d u=d \alpha \\
& \text { or } \quad\left(1-\operatorname{MCF}\left(p-p^{*}\right) \chi_{I}\right) \cdot e_{u} d u=d \alpha \\
& \text { or } \quad e_{u} d u=\left[1 /\left(1-M C F\left(p-p^{*}\right) \chi_{I}\right)\right] \cdot d \alpha=F X M \cdot d \alpha
\end{aligned}
$$

which shows that FXM is the value placed by the private sector on a one-unit transfer from the rest of the world to the private sector.

To interpret the MCF, we begin with equations $\left(4^{\prime}\right)$ and $\left(5^{\prime}\right)$ and consider the case of an exogenous $d \beta$ where $d p$ and $d \alpha$ are endogenously determined, and $d u=0$. As in Section II, we assume the government balances its budget by changing taxes in a particular way and use $\mathrm{dp}=\_\mathrm{d} \varphi$ to solve $\left(3^{\prime}\right)$ for the scalar $\mathrm{d} \varphi$ yielding:

$$
\mathrm{d} \varphi=-1 /\left[\mathrm{e}_{\mathrm{p}}{ }^{\prime}-+\left(\mathrm{p}-\mathrm{p}^{*}\right)^{\prime} \mathrm{e}_{\mathrm{p} p}\right] . \mathrm{d} \beta
$$

Substituting the resulting value of dp into $\left(4^{\prime}\right)$ with $d u=0$ yields the expression for the change in the transfer to the private sector required to maintain utility given the change in the government's transfer to the rest of the world:

$$
\mathrm{d} \alpha=-\mathrm{e}_{\mathrm{p}-} /\left[\mathrm{e}_{\mathrm{p}-}{ }^{\prime}+\left(\mathrm{p}-\mathrm{p}^{*}\right)^{\prime} \mathrm{e}_{\mathrm{pp}-}\right] \cdot \mathrm{d} \beta=- \text { MCF.d } \beta
$$


This shows that the MCF can be interpreted as the compensation from the rest of the world to the private sector required to offset a change in government revenues raised and transferred to the rest of the world. It will not generally be unity because of the changes in the volume of taxed goods associated with the changes in consumer prices resulting from the tax changes the government uses to adjust to the change in its transfer to the rest of the world.

\section{To interpret the money metric value of a transfer to the government}

If we assume that the government receives an increased transfer from the rest of the world, $\mathrm{d} \beta$, and that it refunds this to the household by a reduction in taxes, and that the household responds to the consequent increase in income by adjusting its spending on taxed goods, we can use equations (12) and (13) to assess the consequent money-metric change in welfare:

$$
\mathrm{e}_{\mathrm{u}} \mathrm{du}=\text { FXM.MCF.d_ }
$$

The MCF term adjusts the transfer from its value in the hands of government to its value as a transfer to the private sector, allowing for the benefits associated with the government's ability to lower its tax rates. The FXM term adjusts the value from that of a transfer to the private sector to its money metric valuation, allowing for the income effects on volumes of taxed goods. 


\section{References}

Anderson, J. E. and Martin, W. 1996. The welfare analysis of fiscal policy: a simple unified account, Working Paper No. 316, Department of Economics, Boston College.

Anderson, J.E. and Neary, J.P. 1992. Trade reform with quotas, partial rent retention, and tariffs. Econometrica 60(1), 57-76.

Atkinson, A. and Stern, N. 1974. Pigou, taxation and public goods. Review of Economic Studies 41, 119-128.

Auerbach, A. 1985. The theory of excess burden and optimal taxation. in Auerbach, A. and Feldstein, M. eds. Handbook of Public Economics, Vol 1. North Holland, Amsterdam.

Auten, G. and Carroll, R. 1999. The effect of income taxes on household income. Review of Economics and Statistics 81(4), 681-93.

Ballard, C. 1990. Marginal welfare cost calculations: differential analysis versus balancedbudget analysis. Journal of Public Economics 41, 263-76.

Ballard, C. and Fullerton, D. 1992. Distortionary taxes and the provision of public goods. Journal of Economic Perspectives 6(3), 117-31.

Browning, E. 1976. The marginal cost of public funds. Journal of Political Economy 84, 283-98.

Browning, E. 1987. On the marginal welfare cost of taxation. American Economic Review 77(1), 11-23.

Creedy, J. 2000. Measuring welfare changes and the excess burden of taxation. Bulletin of Economic Research 52(1), 1-47.

Dahlby, B. 1998. Progressive taxation and the social marginal cost of public funds. Journal of Public Economics 67, 105-122.

Deaton, A. and Muellbauer, J. 1980. Economics and Consumer Behavior. Cambridge University Press, Cambridge.

Devarajan, S., Squire, L. and Suthiwart-Narueput, S. 1997. Beyond rate of return: reorienting project appraisal. World Bank Research Observer 12, 35-46.

Diamond, P. and Mirrlees, J. 1971. Optimal taxation and public production. American Economic Review 61, 8-27 and 261-78, March and June.

Drèze, J. and Stern, N. 1987. The theory of cost-benefit analysis. in Auerbach, A. and Feldstein, M., eds., Handbook of Public Economics, Vol II. Elsevier North Holland, Amsterdam.

Feldstein, M. 1995. The effect of marginal tax rates on taxable income: a panel study of the 1986 tax reform act. Journal of Political Economy 103(3), 551-72, June.

Feldstein, M. 1997. How big should government be? National Tax Journal 50(2):197-213, June. 
Feldstein, M. 1999. 'Tax avoidance and the deadweight loss of the income tax. Review of Economics and Statistics 81(4), 674-80.

Fullerton, D. (1991), Reconciling recent estimates of the marginal welfare cost of taxation. American Economic Review 81(1), 302-8.

Gruber, J. and Saez, E. 2002. The elasticity of taxable income: evidence and implications. Journal of Public Economics 84, 1-32.

Hatta, T. 1977. A theory of piecemeal policy recommendations. Review of Economic Studies 44(1), 1-21, February.

Jones, C. 2005. Applied Welfare Economics, Oxford University Press, London.

Kaplow, L. 1996. The optimal size of public spending and the distortionary cost of taxation. National Tax Journal 49(4), 513-33. December.

Kaplow, L. 2004. On the (Ir)Relevance of distribution and labor supply distortion to government policy. Journal of Economic Perspectives 18(4), 159-75.

Little, I. and Mirrlees, J. 1974. Project Appraisal and Planning for Developing Countries. Heinemann, London.

Mayshar, J. 1990. On measures of excess burden and their interpretation. Journal of Public Economics 43, 263-89.

Mayshar, J. 1991. On measuring the marginal cost of funds analytically. American Economic Review 81(5), 1329-35.

Neary, J. P. 1995. Trade liberalisation and shadow prices in the presence of tariffs and quotas. International Economic Review 36(3), 531-554, August.

$\mathrm{Ng}$, Yew-Kwang 2000. The optimal size of public spending and the distortionary cost of taxation. National Tax Journal 53(2), 253-72. June.

Parry, I. 2002. Tax deductions and the marginal welfare cost of taxation. International Tax and Public Finance 9:531-552.

Pigou, A. (1947), A Study in Public Finance. Macmillan, London.

Samuelson, P. 1954. The pure theory of public expenditure. Review of Economics and Statistics 36(4), 397-9.

Sandmo, A. 1998. Redistribution and the marginal cost of public funds. Journal of Public Economics 70, 365-82,

Schöb, R. 1994. On marginal cost and marginal benefit of public funds. Public Finance 49(1), 87-106.

Slemrod, J. and Yitzhaki, S. 2001. Integrating expenditure and tax decisions: the marginal cost of funds and the marginal benefit of projects. National Tax Journal LIV(2), 189-201. 
Snow, A. and Warren, R. 1996. The marginal welfare cost of public funds: theory and estimates. Journal of Public Economics 61, 289-305.

Squire, L. 1989. Project evaluation in theory and practice, in Chenery, H. and T. N. Srinivasan, ,eds., Handbook of Development Economics, Volume II. Elsevier Science Publishers, Amsterdam.

Stiglitz, J. and Dasgupta, P. 1971. Differential taxation, public goods and economic efficiency. Review of Economic Studies 38, 151-74, April.

Stuart, C. 1984. Welfare costs per dollar of additional tax revenue in the United States. American Economic Review 80, 557-66, June.

Triest, R. 1990. The relationship between the marginal cost of public funds and marginal excess burden. American Economic Review 80(3), 557-66.

Wildasin, D. 1984. On public good provision with distortionary taxation. Economic Inquiry XXII(2), 227-43.

Pubgoods-wp 